\section{The effectiveness of giving grade, corrective feedback, and corrective feedback-plus-giving grade on grammatical accuracy}

\section{Hashemifardnia, Arash}

Department of English, Faculty of Humanities, Shahrekord Branch, Islamic Azad University, Shahrekord, Iran (Sadi6675@gmail.com)

Namaziandost, Ehsan $\$

Department of English, Faculty of Humanities, Shahrekord Branch, Islamic Azad University, Shahrekord, Iran (e.namazi75@yahoo.com)

Sepehri, Mehrdad

Department of English, Faculty of Humanities, Shahrekord Branch, Islamic Azad University, Shahrekord, Iran (msepehri@iaushk.ac.ir)

Received: 31 October 2018 Available Online: 19 January 2019

Revised: 30 November 2018 DOI: $10.5861 /$ ijrsll.2019.3012

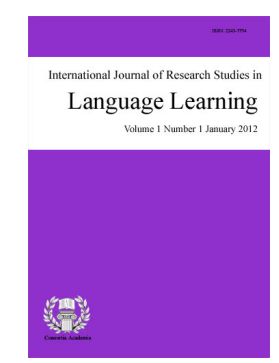

ISSN: 2243-7754 Online ISSN: 2243-7762

OPEN ACCESS

\title{
Abstract
}

This study compared the effects of giving grade, corrective feedback (CF), and CF-plus-giving grade on Iranian pre-intermediate EFL students' learning simple past and simple present tenses. To fulfil this objective, 84 Iranian participants were selected among 80 students based on the results of Oxford Quick Placement Test (OQPT). The selected pre-intermediate participants were then randomly divided into three equal experimental groups; $\mathrm{CF}$-only group ( $n=28)$, grade-only group $(n=28)$, and CF-plus-grade group $(n=28)$. Afterwards, the researchers measured the participants' English grammar knowledge by administering a grammar pre-test including 20 items related to simple past and simple present tenses. After pre-testing, the researchers taught simple present tense to the participants of all groups explicitly. After teaching all points of simple present tense, the researchers gave some homework related to simple present tense to the participants to do at home. In the following session, the researchers checked the participants' homework and gave grade to one group; gave both written and oral CFs to the other group, and gave grades in addition to the CFs to the third group. In the next session, the researchers taught simple past tense to the participants of all groups explicitly. When they taught all related points of simple past tense, they gave some assignments related to simple past tense to the participants to do at home. In the next session, the researchers corrected the participants' homework through giving grade, written and oral CFs, giving grades in addition to the CFs. Finally, a post-test of grammar including 20 objective items related to simple present and simple past tenses was administered to the participants to measure the effects of the treatment on their grammar improvement. The results of One-Way ANOVA and paired-samples t-tests indicated that all experimental groups improved on their post-tests but the CF-plus-grade group had better performance than the other two groups on the post-test. The implications of this study may encourage teachers to use both grades and CFs in the EFL classrooms to correct the EFL learners' grammatical mistakes.

Keywords: grading; corrective feedback; grammatical accuracy 


\section{The effectiveness of giving grade, corrective feedback, and corrective feedback-plus-giving grade on grammatical accuracy}

\section{Introduction}

Grammar is a key concept in general linguistic theory. Grammar is defined as the description of the structure of a language and the way in which linguistic units such as words and phrases are combined to produce sentences in the language (Canale \& Swain, 1980). Grammar is nothing but the sum of rules and regulations of the language. There is ongoing debate regarding the effect of grammar on English language learning from the last few decades (Kumar, Kumar, \& Sagar, 2015). But, it is the fact that grammar plays an important role in second language learning. Knowing a language means commanding over its four basic skills- Listening, Speaking, Reading and Writing. Therefore, it is impossible to speak English accurately without the use of proper grammar. Canale and Swain (1980) propose that grammatical competence is an integral part of communicative competence. One cannot communicate effectively without having the knowledge of grammar.

Grammar is the study of words and the ways words work together; an invisible force that guides us as we put words together into sentences. Any person who communicates using a particular language, consciously or unconsciously becomes aware of the grammar of that language (Kumar, 2013). Kumar (2013) provided a wonderful example to emphasize the grammar importance; he described a writer has given a beautiful analogy to illustrate the use of knowledge of grammar. Imagine two car drivers. The first driver knows only driving and nothing about the working of the engine. He feels helpless whenever there is some trouble with the machinery. The second driver knows driving and also understands the working of the machinery. The person who knows grammar is like this second driver. In this case, he is doubtful about the correctness of a particular thing, his knowledge of grammar comes to his rescue (Kohli, 1984). Therefore, to speak in a clearer and more effective manner we have to study grammar. For the person who has unconscious knowledge of grammar, it may be sufficient for simple language use. But the persons who wish to communicate in the artistic manner with well-defined structures must go for the greater depth of understanding and proficiency of what the study of grammar offers (Kumar, 2013).

To improve EFL learners' grammar knowledge, corrective feedback (CF) may work positively. The term corrective feedback has recently been imperative part of the foreign language teaching. As its name refers, corrective feedback is used to give information on correctness of learner's utterances and provide them with the correct form of their erroneous production. Grami (2005) defines feedback in general as "any procedures used to inform a learner whether an instructional response is right or wrong" (p. 141). According to Lyster and Ranta (1997), there are different kinds of feedback: explicit correction, recast, clarification, metalinguistic feedback, elicitation, and repetition. It is the teachers' task to decide which kind of feedback to be used. However, this decision should be based on the teachers' regards as to which type of feedback can bring the most effective outcome.

The other way that we can improve EFL learners' grammar knowledge is giving grades. Grades are thought to encourage performance-avoidance goals. Pulfrey, Buchs and Butera (2011) argue that "having a performance evaluated with a grade is likely to increase the level of performance-avoidance goals, precisely because the individual being evaluated is in a position of dependence and powerlessness" (p. 685). However, grades are part of learners' destiny and no doubt they should define all language skills. For a dialogue that a learner role-plays or after a composition that he/she write there is almost always a grade.

Regarding the importance of corrective feedback and giving grades, this study aimed to compare their effects on developing Iranian EFL learners' grammar learning. 


\section{Theoretical background}

\subsection{Corrective Feedback}

In writing classes, corrective feedback is defined as a teacher's indication given to students in order to let them know that their written work contains errors (Lightbown \& Spada, 1999). There are many different terms in calling this technique, such as corrective feedback, error correction, and negative evidence (Karim \& Nassaji, 2013). It doesn't matter which term is used since they share the same objective which is to inform students that errors do exist in their written work, and it needs a correction. The better-known teacher corrective feedback is teacher written feedback. This type of feedback is provided by a teacher by means of writing their comments, correction of errors, and others, on students' pieces of writing. As the focus of the present review article is grammatical correction, the feedback concerning grammar improvement is reviewed and discussed. Teacher corrective feedback that involves grammar correction is form-focused feedback (Farrokhi \& Sattarpour, 2011; Razali \& Jupri, 2014).

According to past studies, this type of feedback can be divided into two groups: focused and unfocused. The first one refers to the correction of the targeted grammatical errors frequently made by most of the students, and the teacher finds that they may become serious without any correction. The latter one concerns global errors when teachers correct all grammatical errors found in students' written work. Scholars (Eslami, 2014; Farrokhi \& Sattarpour, 2011) state that focused feedback type is more effective because students can focus on one small error at a time which can eventually help them avoid making that error in the future. A great number of studies reported the effectiveness of teacher written feedback. Among those studies, Ellis, Loewen, and Erlam (2006) indicate that written feedback helps improve students' use of past tense with -ed ending. Bitchener (2008) also states that written corrective feedback benefits EFL writers' writing performance in both short and long term. Later, Sarvestani and Pishkar (2015) pointed out that written feedback type assists students to accurately use English articles.

Lyster and Ranta (1997) distinguished six types of feedback, namely explicit correction, recasts, clarification requests, metalinguistic feedback, elicitation, and repetition:

$>$ Explicit correction: clearly indicating that student's sentence was wrong and the teacher provides the correct form.

$>$ Recast: Recast is a kind of corrective feedback in which teachers without directly showing that the student's utterance was incorrect, they implicitly reformulates the student's error, or provides the correction.

$>$ Clarification: Teachers by using phrases like "excuse me" or "I don't understand" show that the message has not been understood or that the student's utterance includes some kind of error and that a repetition or a reformulation is required.

$>\quad$ Metalinguistic Clues: In this kind of feedback the teacher poses questions or provides comments or information related to the learner's utterance.

$>\quad$ Repetition: the teacher repeats the student's error and adjusts intonation to draw student's attention to it.

\subsection{Grading}

The most common type of feedback that students receive in a typical classroom is grades, more often than not a letter grade or a numeric score by itself (Oosterhof, 2001). Grades provide a convenient summary of students' performance and inform all interested parties of students' achievement. The versatility of the uses of 
grades is emphasized by many measurement experts (Nitko \& Brookhart, 2007). Airasian (1994) listed five main functions that grades serve:

$>$ Administrative - by dealing with decisions concerning matriculation, retention, and entrance into college.

$>$ Guidance - by helping counselors provide direction to students.

$>\quad$ Instructional planning - by informing teachers about students' level of attainment in order to group them for instruction.

$>$ Feedback - to provide students with information about their progress and achievement.

$>$ Motivation - to encourage students to try harder.

It is clear that Functions 1 through 3 of Airasian's (1994) list are summative in nature, whereas 4 and 5 are formative. In the former case, grades are used to inform third parties about students' level of attainment to provide grounds for making critical educational decisions. In the latter case, grades are provided to students themselves and are assumed to facilitate students' learning by influencing their motivation and performance. Although it is hard to disagree with the convenience and effectiveness of grades when used for summative purposes, the formative function of grades as tools that lead to progress in learning has long been disputed.

\subsection{The Concept of Grammar}

As regards the present days, the concept of grammar is polysemous, as it can indicate the internal functioning of the linguistic system; learners' explicit knowledge of the language, which is described by grammars; and the metalinguistic model used to describe that explicit knowledge (Giunchi, 1990). In addition, the definition of grammar is not an univocal one. The most traditional description of grammar is given by Bade (2008), who presented it as the structure of a language, a set of rules that shows changes in words and the way they connect together to form new units. Rivers (1968) added that grammar is often seen as a set of rules, which are expressed with a difficult terminology and have many exceptions. However, these positions are challenged by a different view of grammar, which has been developed in recent years. Today grammar is not considered as a mere set of morphosyntactic rules, but as a means to communicate, that is to mediate words and context (Duso, 2007). In this way, grammar becomes a set of rules that allow the speaker to understand a language and produce correct utterances.

Duso (2007) also listed the different levels to which the concept of grammar refers: the phonological level, which includes pronunciation, rhythm and intonation; the sociolinguistic level, which involves the varieties and registers of a language; the lexical level, which consists of semantics and morphology; the pragmatic level, that is to say the communicative acts carried out through language; and the textual level, which embodies the elements of a text and the different kinds of texts. Also, Larsen-Freeman (1991) explained the same thing from another point of view, asserting that there are three dimensions to deal with when teaching grammar, which are: the form of structures, that is how linguistic structures are built; the meaning of the structures, which is lexical but also grammatical; and the pragmatic conditions that govern the use of structures, such as the relationship between grammar and context. These are interconnected parts of the same unit, and thus they are not organized hierarchically, but they are all at the same level of importance.

In addition, Willis (2003) identified three different kinds of grammar. First, the grammar of structure describes the way in which language items link together to form larger units, such as the noun phrase; it is governed by rules and its learning is supported by instruction. Second, the grammar of orientation includes those features that allow the speaker to relate the elements of a sentence, such as verb tense. Finally, pattern grammar describes patterns associated with words; this is useful because the building of patterns provides the learner with phrases ready to use during communication. Lastly, the importance of pedagogical grammar is underlined by 
Giunchi (1990), who described it as a grammar that has the main aim of enriching learners' ability to use the foreign language, starting from the point of view of the non-native speaker.

\section{Empirical Background}

Regarding the effects of grades and corrective feedbacks on English language learning some empirical studies have been conducted, for example, Rahimi (2009) examined the impact of written corrective feedback on Iranian EFL learners' writing accuracy over time. To do this study, two groups of participants were chosen: one that received indirect feedback and a control group which received general comments and no written corrective feedback. The participants of both groups were required to write four essays during a semester. The errors of the experimental group were underlined and coded with the grammar categories. After the semester ended, the participants were interviewed, the results of which indicated that those who did not receive written corrective feedback on their grammatical structures were discouraged and demotivated. Furthermore, the findings of the study revealed that corrective feedback helps learners develop their writing over time.

In another comparative research, Dlaskaa and Krekeler (2013) investigated the influence of grades on the effectiveness of CF on L2 writing. Three groups of adult learners of German took part in the experiment $(n=226)$. Participants produced three texts. Text 1 was written as a draft, text 2 was a revision of the draft and text 3 was an entirely new text on a different topic. The first group received $\mathrm{CF}$ on all texts (CF-only group), while the second group received grades in addition to the feedback ( $\mathrm{CF}$-and-grades group). The third group did not receive $\mathrm{CF}$, but their texts were graded (grades-only group; control group). CF was directed at morphology and syntax only. The study found no significant effects of grading on performance.

Daneshvar and Rahimi (2014) investigated the effect of both direct focused and recast written corrective feedback (WCF) on grammatical accuracy of EFL learners' writing. The study also sought to examine whether the effect of direct focused or recast WCF was retained over time. For this, 90 low-intermediate female students were selected through Preliminary English Test (PET) and randomly assigned into three groups: two experimental groups (direct focused and recast) and one control group. The study had a quasi-experimental design with pre-tests, immediate post-tests and delayed post-tests. Group A received direct focused written corrective feedback, group B received recast written corrective feedback and the control group $\mathrm{C}$ received no feedback. The statistical analysis indicated that, both experimental groups performed better than the control group and the second experimental group (i.e., the recast group) outperformed the direct focused group. In addition, the lasting effect of recast was more than the lasting effect of direct focused on the grammatical accuracy of EFL learners' writing.

Soltanabadi Farshi and Khalili Safa (2015) compared the effects of two types of corrective feedback on EFL learners' writing skill. Thirty five advanced learners in three groups participated in this study. Structures of written texts were taught in all three classes during fourteen sessions of treatment; and each session, a related topic was given and the learners were asked to write about it. In class A, the learners had to deliver their assignments to the teacher in classroom; then the teacher wrote the corrective notes on their papers and gave their papers back the next session. In class B, students had to write their assignments on their electronic instruments, and after that send written tasks via email to the teacher, and he also sent the corrective comments on their errors through email. In class C, as control group, no corrective feedback was given to learners' errors in their written tasks. Moreover, in class $\mathrm{C}$, learners were free to deliver their writings whether in class or by email. The obtained results showed both methods to be effective since the scores of both experimental groups were significantly higher than the scores of control group, but electronic feedback was more effective and profitable than traditional type; because scores of the learners in group B (Electronic feedback) were significantly higher than class $\mathrm{C}$ (Traditional feedback).

Khanlarzadeh and Nemati (2016) investigated the impact of using direct unfocused WCF on the grammatical accuracy of elementary students in Iranian EFL context. To this end, two intact classes were 
Hashemifardnia, A., Namaziandost, E., \& Sepehri, M.

selected and considered as a direct feedback group $(n=16)$ and a control group $(n=17)$. The participants produced eight pieces of writing (a pretest, three writing tasks along with their revisions, and a posttest) from which their grammatical accuracy was obtained. The final findings uncovered that while the experimental group remarkably outperformed the control group in the revision of the three writing tasks, no significant difference was observed when the two groups produced a new piece of writing after a one-month interval.

\subsection{Significance of the Study}

Having reviewed the literature, it is crystal clear that few studies have been conducted to compare the effects of giving grades and corrective feedbacks on English language learning in general and on grammar in specific. Therefore, this study endeavored to uncover whether Iranian EFL learners benefit more from grades, feedbacks or both. This study can be significant since the researchers used a comparative method of collecting the data. Since comparative studies on grades and feedbacks are in rare, this study employed a novel method in gathering the data, meaning that the researchers used both grades and feedbacks to teach students learn grammar. The current study is among the few that compared giving grades and feedbacks. This research can be significant since it can enrich the growing body of comparative research in the area of grade and feedback.

\subsection{Research Questions and Null Hypotheses}

This study tried to answer the following research questions:

$>$ RQ1. Does giving grade have any significant effect on Iranian pre-intermediate EFL learners' grammatical accuracy (simple past and simple present tenses)?

$>\quad$ RQ2. Does corrective feedback have any significant effect on Iranian pre-intermediate EFL learners' grammatical accuracy (simple past and simple present tenses)?

$>\quad$ RQ3. Do corrective feedback plus giving grade have any significant effect on Iranian pre-intermediate EFL learners' grammatical accuracy (simple past and simple present tenses)?

Based on the above-mentioned questions, the following null hypotheses were suggested in this study:

$>$ HO1. Giving grade does not have any significant effect on Iranian pre-intermediate EFL learners' grammatical accuracy (simple past and simple present tenses).

$>$ HO2. Corrective feedback does not have any significant effect on Iranian pre-intermediate EFL learners' grammatical accuracy (simple past and simple present tenses).

$>$ RQ3. Corrective feedback plus giving grade do not have any significant effect on Iranian pre-intermediate EFL learners' grammatical accuracy (simple past and simple present tenses).

\section{Method}

\subsection{Participants}

To do this research, 84 participants were selected among 113 Iranian junior high school students based on the results of Oxford Quick Placement Test (OQPT). The participants of this study were selected through non-random sampling method since only pre-intermediate level students were included. All the participants were male and their native language was Persian. The target participants were randomly divided into three experimental groups; CF-only group ( $n=28)$, grade-only group $(n=28)$, and CF-plus-grade group $(n=28)$. 


\subsection{Instruments}

The first instrument which was utilized in the present study to homogenize the participants was the OQPT. It could help the researchers to have a greater understanding of what level (i.e., elementary, pre-intermediate, intermediate) their participants were at. This test has 60 multiple-choice items and based on it the learners whose scores were 0 to 10 were beginners; the leaners whose scores were 11 to 17 were considered as breakthrough; the learners whose scores were 18 to 29 were elementary; those learners whose scores were 30 to 39 were preintermediate; the students whose scores were 40 to 47 were intermediate; the learners whose scores were 48 to 54 were considered as the advanced learners and those whose scores were 55 to 60 were very advanced learners. Based on the results of this test, 84 pre-intermediate students were regarded as the target participants of the current research.

The second instrument for gathering data to answer the research questions of the study was a researcher-made grammar pre-test which was prepared based on the students' course book (Prospect 3). This test was given to measure the students' grammar knowledge before receiving the treatment. It consisted of 20 objective items; multiple choice and short answer items. The pre-test validity was confirmed by a panel of English experts and its reliability was computed through using KR-21 formula $(r=0.813)$. The pre-test was piloted on another similar group so as to check the feasibility of the test that was going to be administered to the target participants.

The third instrument which was utilized in this study to measure the impact of the treatment on the participants' grammar learning was a researcher-made grammar post-test. The post-test was the modified form of the pre-test. It should be noted that, there were some subtle differences between pre-test and post-test, that is, the order of options and questions was changed to prevent the probable recall of pre-test answers. To ascertain the reliability of the post-test, the researchers run KR-21 formula and it was revealed that $(r=0.813)$. In addition, the post-test was validated by those who had upheld the pre-test.

\subsection{Data Collection Procedure}

At the outset of the study, the participants were homogenized and then they were assigned in three experimental groups- CF-only group, grade-only group, and CF-plus-grade group. After that, the participants were pretested on grammar through a researcher-made grammar test. After pre-testing, the new grammatical points (simple past and simple present tenses) were taught to the experimental groups explicitly. In the first session, the researchers taught simple present tense to the participants of all groups explicitly. After teaching all points of simple present tense, the researchers asked some questions and the participants were required to answer them. In addition, some practices related to simple present tense were given to the participants to complete at home.

In the next session, the participants showed their homework to the researchers to check it. When the researchers checked the participants' homework, they gave only CF (both written and oral) (such as confirmation checks, repetitions, recasts, clarification requests, metalinguistic feedback, and even facial expressions) to one group; on the other hand, they gave grades (1-20) to the other group; and they gave grades in addition to the CF to the other group. In the next session, the researchers taught simple past tense to the participants of all groups explicitly. When they taught all related points of simple past tense, they asked some questions and the participants were required to answer them. Furthermore, the researchers gave some assignments related to simple past tense to the participants to do at home. In the following session, the participants showed their homework to the researchers and the researchers checked and evaluated their performances the same as they evaluated the participants' performances on simple present tense. After teaching tenses of simple present and simple past, a post-test of grammar including 20 objective items related to simple present and simple past tenses was given to the participants to measure the effects of the treatment on their grammar enhancement. 
Hashemifardnia, A., Namaziandost, E., \& Sepehri, M.

\subsection{Data Analysis}

The gathered data were analyzed through using SPSS software, version 22. Firstly, Kolmogorov-Smirnov (K-S) test was used to check the quality of data normality. Secondly, descriptive statistics were calculated. Thirdly, One-Way Anova and paired samples t-test were used to measure the effects of the treatment on the participants' grammar improvement.

\section{Results}

In order to analyze the gathered data, the SPSS software, version 22 software was used.

\section{Table 1}

One-Sample Kolmogorov-Smirnov Test (Groups' Pre and Post-tests)

\begin{tabular}{|c|c|c|c|c|c|c|c|}
\hline \multicolumn{2}{|l|}{ Statistics } & \multirow{2}{*}{$\begin{array}{c}\text { GOPre } \\
28\end{array}$} & \multirow{2}{*}{$\frac{\text { GOPost }}{28}$} & \multirow{2}{*}{$\begin{array}{c}\text { FOPre } \\
28\end{array}$} & \multirow{2}{*}{$\frac{\text { FOPost }}{28}$} & \multirow{2}{*}{$\frac{\text { GFPre }}{28}$} & \multirow{2}{*}{$\frac{\text { GFPost }}{28}$} \\
\hline$n$ & & & & & & & \\
\hline Normal Parameters ${ }^{\mathrm{a}, \mathrm{b}}$ & Mean & 9.85 & 15.33 & 9.87 & 15.03 & 9.83 & 17.4 \\
\hline & $\mathrm{SD}$ & 1.23 & 1.24 & 1.15 & 1.36 & 1.34 & 1.29 \\
\hline \multirow[t]{3}{*}{ Most Extreme Differences } & Absolute & .15 & .10 & .18 & .08 & .19 & .13 \\
\hline & Positive & .09 & .10 & .11 & .08 & .13 & .13 \\
\hline & Negative & -.15 & -.10 & -.18 & -.06 & -.19 & -.09 \\
\hline Test Statistic & & .15 & .10 & .18 & .08 & .19 & .13 \\
\hline Asymp. Sig. (2-tailed) & & $.093^{\mathrm{c}}$ & $.200^{\mathrm{c}, \mathrm{d}}$ & $.074^{\mathrm{c}}$ & $.200^{\mathrm{c}, \mathrm{d}}$ & $.084^{\mathrm{c}}$ & $.200^{\mathrm{c}, \mathrm{d}}$ \\
\hline
\end{tabular}

Table 1 show that the statistics of scores are normal as the results obtained from using SPSS 22. In this case, the parametric statistics like One-Way ANOVA and paired samples t-test can be used to get the final results.

Table 2

Descriptive Statistics of Pre-test (Three Groups)

\begin{tabular}{|c|c|c|c|c|}
\hline Items & $n$ & Mean & $S D$ & $S E$ \\
\hline Grade Only & 28 & 9.85 & 1.23 & .23 \\
\hline Feedback Only & 28 & 9.87 & 1.15 & .21 \\
\hline Grade plus feedback & 28 & 9.83 & 1.34 & .25 \\
\hline Total & 84 & 9.85 & 1.23 & .13 \\
\hline
\end{tabular}

Based on the descriptive statistics in the table above, all three groups' performances on the pre-test were almost the same; the mean scores of grade-only group is 9.85 , the mean of feedback-only group is 9.87 , and the mean score of grade plus feedback group is 9.83 .

Table 3

One-Way ANOVA (Pre-test)

\begin{tabular}{|c|c|c|c|c|c|c|}
\hline Groups & & $S S$ & $d f$ & $M S$ & $F$ & Sig. \\
\hline Between Groups & & .018 & 2 & .009 & .006 & .994 \\
\hline Within Groups & & 125.76 & 81 & 1.55 & & \\
\hline & Total & 125.78 & 83 & & & \\
\hline
\end{tabular}

Table 3 shows the scores of the three groups on the pre-test. Since Sig (.994) is greater than (.05), the difference between the groups is not significant at $(p<.05)$. In fact, they performed the same on the pre-test. In addition, based on the descriptive statistics in the table 4 , the mean scores of grade-only group, feedback-only group, and grade plus feedback group are 15.33, 15.03, and 17.44, respectively, on the posttest. It seems that the grade plus feedback group outperformed the other two groups on the post-test. To ascertain whether or not the difference between the groups is significant, One-way ANOVA is used in table 5. 
Effectiveness of giving grade, corrective feedback, \& corrective feedback/giving grade on grammatical accuracy

\section{Table 4}

Descriptive Statistics of Pre-test (Three Groups)

\begin{tabular}{|c|c|c|c|c|c|}
\hline Items & & $n$ & Mean & $S D$ & $S E$ \\
\hline Grade Only & & 28 & 15.33 & 1.24 & .23 \\
\hline Feedback Only & & 28 & 15.03 & 1.36 & .25 \\
\hline Grade plus feedback & & 28 & 17.44 & 1.29 & .24 \\
\hline & Total & 84 & 15.94 & 1.67 & .18 \\
\hline
\end{tabular}

Table 5

One-Way ANOVA (Post-test)

\begin{tabular}{|c|c|c|c|c|c|c|}
\hline Groups & & $S S$ & $d f$ & $M S$ & $F$ & Sig. \\
\hline Between Groups & & 96.54 & 2 & 48.27 & 28.50 & .000 \\
\hline Within Groups & & 137.16 & 81 & 1.69 & & \\
\hline & Total & 233.70 & 83 & & & \\
\hline
\end{tabular}

Table 5 displays the scores of the three groups on the post-test. Since Sig (.000) is less than (.50), the difference between the groups is significant at $(p<0.05)$. It can be concluded that all groups improved on their post-test.

Table 6

Post-hoc Scheffe Test, Multiple Comparisons (Post-test)

\begin{tabular}{llccc}
\hline \multicolumn{1}{c}{ (I) Groups } & \multicolumn{1}{c}{$(\mathrm{J})$ Groups } & Mean Difference (I-J) & SE & Sig. \\
\hline Grade Only & Feedback Only & .30 & .34 & .684 \\
& Grade plus feedback & $-2.10^{*}$ & .34 & .000 \\
Feedback Only & Grade Only & -.30 & .34 & .684 \\
& Grade plus feedback & $-2.41^{*}$ & .34 & .000 \\
Grade plus feedback & Grade Only & $2.10^{*}$ & .34 & .000 \\
& Feedback Only & $2.41^{*}$ & .34 & .000 \\
\hline
\end{tabular}

Table 6 compares the scores of all groups on the post-test. This table shows that there is not a significant difference between the post-test scores of the grade-only group and the feedback-only group ( $p<.05)$, but there is a significant difference between the post- test scores of the grade-only group and the grade plus feedback group $(p<.05)$. The findings also reveal that there is a significant difference between the post- test scores of the feedback-only group and the grade plus feedback group $(p<.05)$. It can be concluded that the grade plus feedback group had better performance than the other two groups on the post-test of grammar. Paired-sample t-tests were also run to find any possible significant differences in the participants' grammar scores before and after the treatment (Table 7).

Table 7

Paired Samples t-test (Pre and Post-tests of all Groups)

\begin{tabular}{llcccccc}
\hline & Statistics & Mean & SD & SE Mean & $t$ & $d f$ & Sig. (2-tailed) \\
\hline Pair 1 & GO. Post - GO. Pre & 5.48 & 1.76 & .33 & 16.42 & 27 & .000 \\
Pair 2 & FO. Post - FO. Pre & 5.16 & 2.02 & .38 & 13.49 & 27 & .000 \\
Pair 3 & GF. Post - GF. Pre & 7.60 & 1.92 & .36 & 20.95 & 27 & .000 \\
\hline
\end{tabular}

In Table 7, three paired samples t-tests are used to compare the pre and post-tests of each group. The difference between the pre-test and post-test each group is significant since Sig (.000) is less than .05.

\section{Discussion}

In this part the research questions are answered one by one; the first research question is "Does giving grade have any significant effect on Iranian pre-intermediate EFL learners' grammatical accuracy (simple past and 
simple present tenses)?" Based on the results obtained in the tables above, giving grades helped the participants to learn simple past and simple present tenses successfully. The results statistically revealed that grade-only group significantly did better on their grammar post-test $(p<.05)$ compared to their pre-test. Therefore, the first null hypothesis of the study "Giving grade does not have any significant effect on Iranian pre-intermediate EFL learners' grammatical accuracy (simple past and simple present tenses)" is rejected.

Giving grade as a traditional technique in Iranian educational system motivated the participants to learn simple past and simple present tenses. Giving grade may increase the students' motivation, inform their strengths and weaknesses, and encourage them to improve their learning. The results of this study are in contrast to the results discovered by Dlaskaa and Krekeler (2013) who investigated the influence of grades on the effectiveness of CF on L2 writing. They found no significant effects of grading on performance of the participants. Similarly, the findings of this study are in contrast to Elawar and Corno (1985) who examined the impacts of teachers' written feedback on students' homework. The researchers discovered that those participants who received comments outperformed those who received grades.

Grades are thought to encourage performance-avoidance goals. Pulfrey, Buchs, and Butera (2011) argued, for instance, that "having a performance evaluated with a grade is likely to increase the level of performance-avoidance goals, precisely because the individual being evaluated is in a position of dependence and powerlessness" (p. 685). In a series of surveys among students in a Swiss technical college they found that "expectation of a grade, compared with no grade, consistently induced greater adoption of performance avoidance goals" (p. 683). Though several researchers proved the negative effects of giving grade, this study proved opposite results. Grading assisted Iranian EFL learners to increase their motivation in order to encourage them to try harder to make progress in their grammar learning.

The second research question is "Does corrective feedback has any significant effect on Iranian pre-intermediate EFL learners' grammatical accuracy (simple past and simple present tenses)?" The results of this study indicated that receiving CF could help the participants to enhance their grammar learning. Therefore, the second null hypothesis of the study "Corrective feedback does not have any significant effect on Iranian pre-intermediate EFL learners' grammatical accuracy (simple past and simple present tenses)" is rejected. The interaction that happened between the researchers and the participants through CF paved the way for learning grammatical points. As Naeini (2008) stated that learning happens when there is an exchange of information between learners and teachers. Furthermore, he claimed that there should even be a considerable amount of interaction within learners. The positive feedbacks which the participants received motivated them to learn simple past and simple present tenses.

The findings of this study are in contrast to Truscott's point of view (1996) who stated that written corrective feedback has no effect on written grammatical accuracy of learners. On the other hand, this study is supported by Bitchener (2008) who examined the efficacy of focused written corrective feedback to 75 low intermediate ESL students in New Zealand. The study employed three types of written direct corrective feedback and a no-feedback treatment focusing on the use indefinite article "a" and definite article "the". The findings indicated that the accuracy of students in the groups receiving written focused corrective feedback outperformed students who did not receive any feedback. Providing feedback is often considered as one of the most crucial tasks of EFL teachers. Through providing feedbacks, teachers can involve EFL learners in correction process. In other words, teachers can use feedbacks to direct learners' attention to the erroneous points. The attention and involvement of the students can be the reasons of students' grammar improvement in this study.

The third question of this study is "Do corrective feedback plus giving grade have any significant effect on Iranian pre-intermediate EFL learners' grammatical accuracy (simple past and simple present tenses)?" The findings of this study revealed that the participants got higher scores on their post-test compared to the pre-test. This difference can be attributed to the treatment they had received. In fact, CF plus giving grade helped the participants learn simple past and simple present tenses successfully. Therefore, the third null hypothesis of the 
study "Corrective feedback plus giving grade do not have any significant effect on Iranian pre-intermediate EFL learners' grammatical accuracy (simple past and simple present tenses)" is rejected.

It is obvious that $\mathrm{CF}$ and grades together can help EFL learners promote their English leaning. Due to receiving $\mathrm{CF}$, EFL learners can become cognizant of their weak points and consequently they can make effort to remove them. CF can encourage EFL learners to pay more heed to their weak points and also CF can assist them to improve their strong points. Receiving feedback has been revealed to improve learning when it gives each student specific guidance on strengths and weaknesses, preferably without any overall marks (Black \& Wiliam, 1998).

\section{Conclusion}

The current research compared the effects of CF-only, grade-only, and CF-plus-grade on Iranian pre-intermediate EFL learners' simple past and simple present tenses. It was revealed that the three techniques (CF-only, grade-only, and CF-plus-grades) helped Iranian pre-intermediate EFL learners learn simple past and simple present tenses successfully. It should be noted that there was a significant difference between the effectiveness of CF-only, grade-only, and CF-plus-grades on grammar learning; CF-plus-grades was the most effective technique among others (CF-only and grade-only). Accordingly, it can be concluded that providing feedback and giving grade can have a significant effect on the learners' language learning. Feedbacks are advantageous since they build up communication and provide a rich environment for the learners in the classroom. They are mediums of increasing reflection in students although using them is not without drawbacks.

The characteristics of interactive feedback, as meaningful and indirect repetition of the students' performances, make them good instruments for teachers to check the students' errors in the classroom. They can also provide the students with a critical eye to find out the difference between their own performance and their teacher's; and this makes them sensitive to their errors (Long, 2006). Such characteristics lead the feedbacks to become important tools for the correction of the errors. However, the successful integration of the interactive feedbacks into EFL classes is mainly dependent on the teacher's method. Furthermore, learner's needs, attitudes, and proficiency levels should be considered in this regard. In short, feedback is an inherent and crucial part of an instructional design model and has a strong foundation in major learning theories. The role of feedback in the instruction and learning English as second or foreign language is undeniably important. Feedbacks can inform the learners whether their answers are correct or not, as well as provide them with enough information and guidance to produce the correct target form.

\subsection{Implications of the Study}

This research can bring about some pedagogical implications for EFL teachers, learners, and material designers. The findings of the current study can encourage teachers to use corrective feedbacks in teaching English language to help EFL learners correct their errors and increase their language accuracy. The findings can make teachers aware that using both grades and corrective feedbacks can work better in EFL contexts rather than applying only one of them. Besides, English language learners can benefit from the results of the current research. Through corrective feedbacks EFL learners can correct their own errors by the inputs which they receive, therefore, EFL learners can improve their self-correction. EFL learners' autonomy will increase when they correct their own mistakes; in fact, directing learners toward self-correction helps to reduce the reliance on teachers.

The findings of the present study make the syllabus designers get aware of the importance of corrective feedbacks in learning English language. Syllabus designers should emphasize the importance of corrective feedbacks and acquaint teachers with the best methods of corrective feedback. Syllabus designers can incorporate activities and exercises in EFL text books which require learners to improve their own self-correction. In addition, this study can broaden the horizons of those who are willing to conduct researches in domain of feedback. In other words, the findings of this study can pave the way for the future researchers. 


\section{References}

Airasian, P. W. (1994). Classroom assessment (2nd ed.). New York: McGraw-Hill.

Bade, M. (2008). Grammar and good language learners. In C. Griffiths (Ed.), Lessons from good language learners (pp. 174-184). Cambridge: Cambridge University Press. https://doi.org/10.1017/CBO9780511497667.016

Bitchener, J. (2008). Evidence in support of written corrective feedback. Journal of Second Language Writing, 17, 102-118. https://doi.org/10.1016/j.jslw.2007.11.004

Black, P., \& Wiliam, D. (1998). Inside the black box: Raising standards through classroom assessment. Phi Delta Kappan, 80(2), 139-148.

Canale, M., \& Swain, M. (1980). Theoretical bases of communicative approaches to second language teaching and testing. Applied Linguistics, 1(3), 1-47. https://doi.org/10.1093/applin/I.1.1

Daneshvar, E., \& Rahimi, A. (2014). Written corrective feedback and teaching grammar. Procedia-Social and Behavioral Sciences, 136, 217-221. https://doi.org/10.1016/j.sbspro.2014.05.317

Dlaskaa, A., \& Krekeler, C. (2013). Does grading undermine feedback? The influence of grades on the effectiveness of CFon L2 writing. The Language Learning Journal, 10(5), 1-19.

Duso, E. M. (2007). From theory to practice: Grammar in the Italian L2 class. Roma: Aracne editrice.

Elawar, M. C., \& Corno, L. (1985). A factorial experiment in teachers' written feedback on student homework: Changing teacher behavior a little rather than a lot. Journal of Educational Psychology, 77, 162-173. https://doi.org/10.1037/0022-0663.77.2.162

Ellis, R., Loewen, S., \& Erlam, R. (2006). Implicit and explicit corrective feedback and the acquisition of L2 grammar. Studies in Second Language Acquisition, 28, 339-368. https://doi.org/10.1017/S0272263106060141

Eslami, E. (2014). The effects of direct and indirect corrective feedback techniques on EFL students' writing. Procedia Social and Behavioral Sciences, 98, 445-452. https://doi.org/10.1016/j.sbspro.2014.03.438

Farrokhi, F., \& Sattarpour, S. (2011). The effects of focused and unfocused written corrective feedback on grammatical accuracy of Iranian EFL learners. Theory and Practice in Language Studies, 1(12), 1797-1803. https://doi.org/10.4304/tpls.1.12.1797-1803

Giunchi, P. (1990). Explicit and implicit grammar. In P. Giunchi (Ed.), Explicit grammar and implicit grammar (pp. 11-19). Bologna: Zanichelli.

Grami, M. A. (2005). The effect of teachers' written feedback on ESL students' writing: A study on a Saudi ESL University-level context. Language Teaching, 2, 9-22.

Karim, K., \& Nassaji, H. (2013). The role of corrective feedback in second language writing. Iranian Journal of Language Teaching Research, 1(1), 117-134.

Khanlarzadeh, M., \& Nemati, M. (2016). The effect of written corrective feedback on grammatical accuracy of EFL students: An improvement over previous unfocused designs. Iranian Journal of Language Teaching Research, 4(2), 55-68.

Kohli, A. L. (1984). Techniques of teaching English. Delhi: Dhanpat Rai and sons.

Kumar, P. (2013). The importance of grammar in English language teaching - a reassessment. Language in India, 13(5), 482-486.

Kumar, P., Kumar, V., \& Sagar, N. (2015). Role of grammar in English language learning. International Journal of English Language, 3(10), 186-190.

Larsen-Freeman, D. (1991). Teaching grammar. In M. Celce Murcia (Ed.), Teaching English as a second or foreign language (pp. 279-296, 2nd ed.). New York: Newbury House.

Lightbown, P. M., \& Spada, N. (1999). How languages are learned. Oxford, UK: Oxford University Press. Long, M. H. (2006). Problems in SLA. Mahwah: Lawrence Erlbaum.

Lyster, R., \& Ranta, L. (1997). Corrective feedback and learner uptake: Negotiation of form in communicative classrooms. Studies in second language acquisition, 19, 37-66. https://doi.org/10.1017/S0272263197001034

Naeini, J. (2008). Error correction: An indication of consciousness-raising. Novitas Royal, 2(2), 120-140. 
Effectiveness of giving grade, corrective feedback, \& corrective feedback/giving grade on grammatical accuracy

Nitko, A. J., \& Brookhart, S. M. (2007). Educational assessment of students (5th ed.). Upper Saddle River, NJ: Pearson Prentice Hall.

Oosterhof, A. (2001). Classroom applications of educational measurement. Upper Saddle River, NJ: Merrill Prentice Hall.

Pulfrey, C., Buchs, C., \& Butera, F. (2011). Why grades engender performance-avoidance goals: The mediating role of autonomous motivation. Journal of Educational Psychology, 103(3), 683-700. https://doi.org/10.1037/a0023911

Rahimi, M. (2009). The role of teacher's corrective feedback in improving Iranian EFL learners " writing accuracy over time: is learner's mother tongue relevant? Reading and Writing, 22 (2), 219-243. https://doi.org/10.1007/s11145-008-9139-5

Razali, R., \& Jupri, R. (2014). Exploring teacher written feedback and student revisions on ESL students' writing. IOSR Journal of Humanities and Social Sciences, 19(5), 63-70. https://doi.org/10.9790/0837-19556370

Rivers, W. M. (1968). Teaching foreign-language skills. Chicago: The University of Chicago Press.

Sarvestani, M. S., \& Pishkar, K. (2015). The effect of written corrective feedback on writing accuracy of intermediate learners. Theory and Practice in Language Studies, 5(10), 2046-2052. https://doi.org/10.17507/tpls.0510.10

Soltanabadi Farshi, S., \& Khalili Safa, S. (2015). The effect of two types of corrective feedback on EFL learners' writing skill. Advances in Language and Literary Studies, 6(1), 1-5.

Truscott, J. (1996). The case against grammar correction in L2 writing classes. Language Learning, 46(2), 327-369. https://doi.org/10.1111/j.1467-1770.1996.tb01238.x

Willis, D. (2003). Rules, patterns and words: Grammar and lexis in English language teaching. Cambridge: Cambridge University Press. https://doi.org/10.1017/CBO9780511733000 
Hashemifardnia, A., Namaziandost, E., \& Sepehri, M. 